\title{
PENGEMBANGAN MEDIA PEMBELAJARAN MATEMATIKA BERBASIS ANDROID DI KELAS 4 SEKOLAH DASAR
}

\author{
Dini Savitri ${ }^{1}$, Abdul Karim ${ }^{2}$, Hasbullah ${ }^{3}$ \\ ${ }^{123}$ Pendidikan Matematika, Universitas Indraprasta PGRI, Jakarta, Indonesia. \\ dinidinulsavitri@gmail.com¹, abdul_karim@unindra.ac.id ${ }^{2}$, hasbule@gmail.com ${ }^{3}$
}

\begin{abstract}
The purpose of this development research is to produce learning media products that can be used as an alternative effective learning media for learners who can be used for independent learning, so as to improve student learning outcomes. The research was conducted at SDN Sudimara Timur 5. The result of the review by the media expert on all aspects which was assessed the average money obtained was 3.71 which means included in good category, by the material expert obtained an average of 3.75 with good category, And by the user that is equal to 4,625 is also included into the category very well. So as to obtain the average of the overall review of experts and users of learning media developed that amounted to 4.02 which belong to the good category. Based on the review by these experts then the learning media is declared feasible to be implemented in the learning process of students independently.
\end{abstract}

Keywords: Development, Learning Media, Android

\begin{abstract}
Abstrak
Tujuan dari penelitian pengembangan ini adalah menghasilkan produk media pembelajaran yang dapat dijadikan sebagai salah satu alternatif media pembelajaran yang efektif bagi peserta didik yang dapat digunakan untuk belajar mandiri, sehingga dapat meningkatkan hasil belajar peserta didik. Penelitian dilaksanakan di SDN Sudimara Timur 5. Hasil review oleh ahli media terhadap seluruh aspek yang dinilai rata-rata uang diperoleh yaitu sebesar 3,71 yang berarti termasuk dalam kategori baik, oleh ahli materi diperoleh rata-rata sebesar 3,75 dengan kategori baik, serta oleh pengguna yaitu sebesar 4,625 juga termasuk kedalam kategori sangat baik. Sehingga diperoleh rata-rata keseluruhan hasil review ahli dan pengguna terhadap media pembelajaran yang dikembangkan yaitu sebesar 4,02 yang termasuk kedalam kategori baik. Berdasarkan hasil review oleh ahli tersebut maka media pembelajaran ini dinyatakan layak untuk diimplementasikan dalam proses belajar peserta didik secara mandiri.
\end{abstract}

Kata kunci: Pengembangan, Media Pembelajaran, Android

Received: May 04, 2020 / Accepted: July 23, 2020 / Published Online: August 26, 2020 
Jurnal Lebesgue : Jurnal Ilmiah Pendidikan Matematika, Matematika dan Statistika

Dini Savitri, Abdul Karim, Hasbullah

Volume 1, No. 2, Agustus 2020 hal.63-75

DOI Artikel : 10.46306/lb.v1i2.17

\section{PENDAHULUAN}

Berdasarkan hasil riset yang dilaksanakan oleh kementerian kominfo dan UNICEF (kominfo.go.id) (Dewabroto, 2014) bahwa dari 30 juta orang yang terdiri dari anak-anak dan remaja yang berada di Indonesia adalah pengguna internet, dan saluran komunikasi yang menjadi pilihan utama masyarakat saat ini adalah media digital dan ditemukan dari hasil survey, pengguna internet mencapai 80 persen dari jumlah responden yang diteliti. Hasil riset ini mengungkapkan untuk mengakses internet memakai computer sebanyak 69 persen responden. Hampir 34 persen responden memakai laptop, dan hanya 2 persen responden terhubung melalui video game. Selanjutnya, dari 52 persen responden yang disurvei kebayakan mereka menjawab mengunakan hand phone untuk mengakses internet, tetapi hanya sedikit yang menggunakan tablet atau 4 persen responden dan 21 persen responden yang menggunakan smartphone.

Namun seiring dengan perkembangan teknologi pengguna smartphone di Indonesia masih sangat berbanding terbalik dengan pemanfaatan smartphone yang belum optimal khususnya di dunia pendidikan.Ini terlihat dengan banyaknya masih rendahnya rating-rating Media Pembelajaran yang ada. Di kalangan pelajar sendiri, smartphone sebagian besar hanya digunakan untuk mengakses jejaring sosial seperti instagram,, twitter dan facebook namun belum mengambil peranan penting di bidang pendidikan. Sedangkan pada anak Sekolah Dasar, smartphone seringkali hanya digunakan untuk bermain game.

Pada dasarnya jenjang sekolah dasar merupakan jenjang yang memiliki pengaruh besar terhadap keberhasilan pendidikan di jenjang selanjutnya. Selama ini dalam proses belajar mengajar, metode yang diterapkan kurang efektif dan efisien.sehingga anak sekolah tidak tertarik untuk mengikuti pembelajaran. Misalnya menggunakan metode ceramah dimana guru menyampaikan isi meteri kepada peserta didiknya dan peserta didik hanya mendengarkan. Hasilnya peserta didik hanya dapat menguasai secara teoritis saja, sehingga kurang terampildalam memecahkan masalah. Oleh karena itu, seharusnya perkembangan teknologi yang besar ini dapat dioptimalkan oleh guru untuk menunjang proses pembelajaran di sekolah, terutama oleh guru matematika.

Matematika memiliki peranan yang sangat penting dalam kehidupan siswa sekarang dan nanti(Supriyanti, 2020). Dan Salah satu komponen dari serangkaian mata pelajaran yang mempunyai peranan penting dalam pendidikan adalah matematika. Matematika juga merupakan salah satu mata pelajaran yang menunjang perkembangan ilmu pengetahuan dan teknologi. Namun sampai saat ini masih banyak peserta didik yang merasa bahwa matematika adalah mata pelajaran yang mengerikan. Selain mengerikan, matematika juga dianggap sebagai mata pelajaran yang membosankan yang hanya membahas mengenai angka, rumus, gambar dan operasi hitung. Hal inilah yang seharusnya menjadi perhatian khusus oleh para guru untuk menciptakan suasana belajar yang menyenangkan dan tidak membosankan.

Dalam masalah tersebut, peningkatan mutu pendidikan terutama di bidang matematika perlu dilakukan untuk mengantisipasi perkembangan teknologi yang tidak lepas dari perkembangan 
Jurnal Lebesgue : Jurnal Ilmiah Pendidikan Matematika, Matematika dan Statistika

Dini Savitri, Abdul Karim, Hasbullah

Volume 1, No. 2, Agustus 2020 hal.63-75

DOI Artikel : 10.46306/lb.v1i2.17

matematika. Ada banyak alasan tentang perlunya peserta didik untuk belajar matematika. Ada lima alasan menurut Cornelius (Mulyono, 2003) perlunya belajar matematika, dikarena matematika merupakan : (1) Fasilitas berpikir yang jelas dan logis, (2) Fasilitas untuk memecahkan masalah kehidupan sehari-hari, (3) Fasilitas mengenal pola-pola hubungan dan generalisasi pengalaman (4) Fasilitas untuk mengembangkan kreativitas, dan (5) Fasilitas untuk meningkatkan kesadaran terhadap perkembangan budaya.

Semakin merambahnya penggunaan smartphone di kalangan pelajar membuka peluang besar bagi para pendidik, khususnya praktisi pendidikan dalam bidang matematika. Pembelajaran matematika (Fatimah, 2009) adalah membentuk logika berpikir bukan sekedar berhitung. Berhitung dapat menggunakan alat bantu, seperti komputer dan kalkulator, namun logika berfikir dan analisis digunakan untuk menyelesaikan masalah. Oleh karena itu, pemahaman yang benar dan lengkap sesuai dengan tahapan harus dimiliki oleh peserta didik dalam belajar matematika. Pemahanan yang benar dengan cara yang menyenangkan dengan menjalankan prinsip pembelajaran matematika.

Media pembelajaran saat ini sangat dibutuhkan oleh para pendidik untuk meningkatkan minat belajar peserta didik dan mempermudah proses pembelajaran. Dengan demikian para pendidik wajib menguasai berbagai media pembelajaran yang dianggap cocok untuk berbagai materi dalam pembelajaran matematika. Dengan minciptakan media pembelajaran yang memanfaatkan smartphone dapat meningkatkan minat peserta didik dalam belajar. Media pembelajaran (Sundayana, 2014) adalah sebuah perangkat yang digunakan dan berfungsi untuk pesan pembelajaran Media pembelajaran merupakan salah satu upaya pengadaan media pembelajaran yang inovtif dan tepat guna. Sehingga pada akhirnya diharapkan dapat meningkatkan mutu pendidikan dan pembelajaran yang lebih menarik.

Pengembangan perangkat mobile tersebut sebagai salah satu cara para guru atau pendidik dalam memanfaatkan teknologi di era digital ini. Pengembangan (Rita C. Richey \& Klein, 2007) "Development is the process of translating the design specifications into physical form related to the systematic study design, development and evaluation process with a view establish an empirical basis for the creation of non-learning products and learning new or enhanced models of existing development". Pengembangan adalah proses penerjemahan spesifikasi desain ke dalam bentuk fisik yang berkaitan dengan desain belajar sistematik, pengembangan dan evaluasi memproses dengan maksud menetapkan dasar empiris untuk mengkreasikan produk pembelajaran dan non-pembelajaran yang baru atau model peningkatan pengembangan yang sudah ada.

Aplikasi yang sangat digemari oleh setiap orang adalah android. (Safaat, 2014) Android adalah sebuah sistem operasi untuk perangkat mobile berbasis linux yang mencakup sistem operasi, middleware dan aplikasi. Android menyediakan platform terbuka bagi para pengembang untuk menciptakan aplikasi mereka. Pada dasarnya, android merupakan perangkat lunak yang dibuat khusus untuk perangkat portable yang bersifat bebas dan terbuka. Pengembangan aplikasi android dapat dibuat dengan dukungan beberapa software, salah satunya adalah dengan menggunakan App Inventor. 
Jurnal Lebesgue : Jurnal Ilmiah Pendidikan Matematika, Matematika dan Statistika

Dini Savitri, Abdul Karim, Hasbullah

Volume 1, No. 2, Agustus 2020 hal.63-75

DOI Artikel : 10.46306/lb.v1i2.17

Aplikasi App Inventor ini pada dasarnya adalah aplikasi yang disediakan oleh google dan sekarang dimaintenance oleh Massachusetts Institute of Technology (MIT). Aplikasi ini selesai dibuat pada 12 juli 2010 dan dirilis untuk public pada 31 Desember 2011. App Inventor sekarang dipegang oleh MIT Centre for Mobile Learning dengan nama MIT App Inventor.

Dari hasil penelitian yang dilakukan oleh (Rohmi et al., n.d.) dalam pengembangan aplikasi android pada materi dimensi tiga untuk peserta didik SMA kelas X. Aplikasi android yang dirancang memiliki enam menu utama yaitu kompetensi, prasyarat, materi, evaluasi, glosarium dan tentang aplikasi. Penelitian ini fokus pada materi dimensi tiga yang dianggap sulit oleh peserta didik dalam memahami kedudukan titik, garis dan bidang pada bagun dimensi tiga yang digambar pada bidang datar. Ada dua keterbatasan dalam kajian penelitian tersebut pertama kurangnya ragam contoh dan pada soal evaluasi tidak dirancang interaktif sehingga ada kemungkinan peserta didik ada kemungkinan menghafal jawabnya. Kedua aplikasi android yang digunakan yaitu Adobe AIR yang ketika dijadikan $A P K$ menjadi lebih berat ketika di install di handphone. Oleh karena itu, penelitian ini dimaksudkan membuat pengembangan media pembelajaran berbasis android dengan menggunakan aplikasi App Inventor yang dirasa lebih ringan untuk dinstal di handphone dan pembelajaran dapat dilakukan secara mandiri oleh peserta didik dirumah. Adapun Tujuan penelitian ini adalah menghasilkan produk media pembelajaran yang dapat dijadikan sebagai salah satu alternatif media pembelajaran yang efektif bagi peserta didik, sehingga dapat meningkatkan hasil belajar peserta didik pada materi kelas empat SD.

Melihat beberapa masalah diatas, dimana penggunaan smartphone yang belum optimal di dunia pendidikan, dan kurangnya inovasi untuk menciptakan pembelajaran dan pemahaman matematika yang mudah diterima peserta didik, maka munculah sebuah gagasan untuk menciptakan sebuah media pembelajaran yang dapat dijadikan sebagai salah satu alternatif media pembelajaran yang efektif bagi peserta didik yang dapat digunakan untuk belajar mandiri, sehingga dapat meningkatkan hasil belajar matematika.

\section{METODE PENELITIAN}

Penelitian yang bertempat di SDN Sudimara Timur 5 Ciledug, Tanggerang menggunakan metode Penelitian yang digunakan adalah Penelitian pendidikan dan pengembangan. (Borg \& Gall, 1983) "Educational Research and development ( $R \& D)$ is a process used to develop and validate educational products.". Penelitian Pendidikan dan pengembangan ( $\&$ D) adalah proses yang digunakan untuk mengembangkan dan memvalidasi produk pendidikan. Pada pengembangan media pembelajaran ini model pengembangan yang digunakan yaitu model ADDIE (Analysis, Design, Development, Implementation, and Evaluation). ADDIE Model pengembangan ADDIE mencakup aspek Analysis (analisis), Design (perancangan), Development (pengembangan), Implementation (penerapan), dan Evaluation (evaluasi). Kelima fase tersebut dilakukan secara sistematik, berikut adalah langkah-langkah model pengembangan ADDIE :

Langkah 1. Analysis (analisis) 
Jurnal Lebesgue : Jurnal Ilmiah Pendidikan Matematika, Matematika dan Statistika

Dini Savitri, Abdul Karim, Hasbullah

Volume 1, No. 2, Agustus 2020 hal.63-75

DOI Artikel : 10.46306/lb.v1i2.17

Tahap analisis merupakan suatu proses analisis kebutuhan, dan mengidentifikasi masalah (kebutuhan). Analisis dilakukan untuk mengetahui apa tujuan dilakukannya pengembangan media ini dan ditujukan kepada siapa media ini.

Langkah 2. Design (disain / perancangan)

Tahap ini dikenal dengan istilah membuat rancangan media yang akan dikembangkan. Perencanaan dilakukan berdasarkan hasil dari analisis pada langkah sebelumnya.

Langkah 3. Development (pengembangan)

Tahap ini merupakan proses mewujudkan rancangan desain yang tadi menjadi kenyataan. Artinya pada tahap ini segala sesuatu yang dibutuhkan atau yang akan mendukung proses pembelajaran semuanya harus disiapkan. Hasil dari tahap ini adalah produk awal dari aplikasi yang dikembangkan.

Langkah 4. Implementation (implementasi/eksekusi)

Implementasi adalah langkah nyata untuk menerapkan sistem pembelajaran yang sedang kita buat. Artinya, pada tahap ini semua yang telah dikembangkan diinstal atau diset sedemikian rupa sesuai dengan peran atau fungsinya agar bisa diimplementasikan. Setelah produk siap, maka dapat diuji cobakan melalui kelompok besar kemudian dievaluasi dan direvisi. Uji coba dapat dilakukan pada kelompok besar kemudian dievaluasi kembali dan direvisi sehingga menghasilkan produk akhir yang siap diluncurkan.

Langkah 5. Evaluation (evaluasi/ umpan balik)

Evaluasi adalah proses untuk melihat apakah sistem pembelajaran yang sedang dibangun berhasil, sesuai dengan harapan awal atau tidak. Tahap evaluasi bisa dilakukan pada setiap 4 tahap diatas yang disebut evaluasi formatif, karena tujuannya untuk kebutuhan revisi. Misalnya pada tahap rancangan kita memerlukan review ahli untuk memberikan input terhadap rancangan yang sedang kita buat.

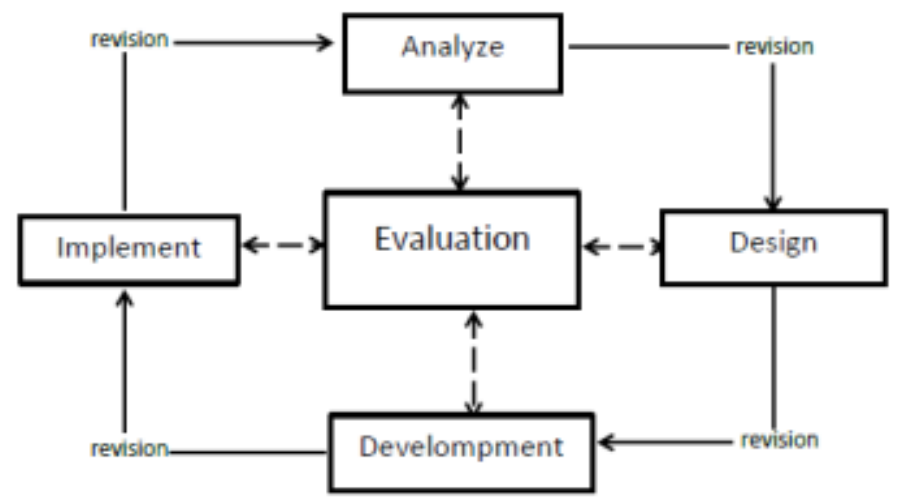

\section{Gambar 1: Model Pengembangan Pembelajaran ADDIE}

Teknik yang digunakan untuk pengumpulan data pada penelitian ini dilakukan dengan wawancara dan angket. Wawancara dilakukan untuk memperoleh analisis kebutuhan awal produk yang akan dibuat. Angket digunakan untuk mengetahui pendapat responden atau peserta didik tentang media pembelajaran yang dibuat. 
Jurnal Lebesgue : Jurnal Ilmiah Pendidikan Matematika, Matematika dan Statistika

Dini Savitri, Abdul Karim, Hasbullah

Volume 1, No. 2, Agustus 2020 hal.63-75

DOI Artikel : 10.46306/lb.v1i2.17

Untuk menguji kelayakan media oleh pengguna, maka instrumen pengumpulan data yang digunakan adalah lembar penilaian yang telah diverifikasi oleh dosen yang berkopetensi. Indikator yang dinilai dalam penelitian ini meliputi beberapa aspek diantaranya kejelasan visual, kemudahan, estetika dan kebutuhan pengguna.

Kisi-kisi angket penilaian media pembelajaran ini dapat dilihat pada tabel berikut.

Tabel 1. Kisi-kisi penilaian Ahli media

\begin{tabular}{|c|c|c|c|c|}
\hline No & Aspek & Indikator & $\begin{array}{l}\text { Nomor Item } \\
\text { Pertanyaan }\end{array}$ & Jumlah \\
\hline 1. & Kejelasan Visual & $\begin{array}{ll}\text { a. } & \text { Kejelasan teks } \\
\text { b. } & \text { Kesesuaian gambar dengan } \\
& \text { materi }\end{array}$ & 1,2 & 2 \\
\hline 2. & Kemudahan & Kemudahan penggunaan media & 3 & 1 \\
\hline 3. & Estetika & $\begin{array}{l}\text { a. Tampilan Media } \\
\text { b. Warna yang digunakan }\end{array}$ & 4,5 & 2 \\
\hline 4. & $\begin{array}{r}\text { Kebutuhan } \\
\text { Pengguna }\end{array}$ & $\begin{array}{l}\text { a. Kebutuhan pengguna terhadap } \\
\text { media } \\
\text { b. Kelayakan media }\end{array}$ & 6,7 & 2 \\
\hline & nlah & & & 7 \\
\hline
\end{tabular}

Sumber: (Mubarok, 2015) dengan modifikasi

Tabel 2. Kisi-kisi penilaian ahli materi

\begin{tabular}{|c|c|c|c|c|}
\hline No & Aspek & Indikator & $\begin{array}{l}\text { Nomor Item } \\
\text { Pertanyaan }\end{array}$ & Jumlah \\
\hline 1. & $\begin{array}{c}\text { Kesesuaian } \\
\text { Materi }\end{array}$ & $\begin{array}{ll}\text { a. } & \text { Kesesuaian dengan kompetensi } \\
& \text { dasar } \\
\text { b. Kesesuaian dengan tujuan } \\
\text { pembelajaran } \\
\text { c. Kesesuaian gambar dengan } \\
\text { materi } \\
\text { d. Kejelasan contoh }\end{array}$ & $1,2,3,4$ & 4 \\
\hline 2. & Kemudahan & Kemudahan penggunaan media & 5 & 1 \\
\hline 3. & $\begin{array}{l}\text { Kebutuhan } \\
\text { pengguna }\end{array}$ & $\begin{array}{l}\text { a. Mendorong perkembangan } \\
\text { afektif peserta didik } \\
\text { b. Kebutuhan kejelasan jawaban } \\
\text { c. Kelayakan media } \\
\text { d. }\end{array}$ & $6,7,8$ & 3 \\
\hline & & Jumlah & & 8 \\
\hline
\end{tabular}

Sumber: (Mubarok, 2015) dengan modifikasi 
Tabel 3. Kisi-kisi penilaian pengguna

\begin{tabular}{|c|c|c|c|c|}
\hline No & Aspek & Indikator & $\begin{array}{l}\text { Nomor Item } \\
\text { Pertanyaan }\end{array}$ & Jumlah \\
\hline 1. & Kejelasan Visual & $\begin{array}{ll}\text { a. } & \text { Kejelasan teks } \\
\text { b. Kesesuaian gambar dengan } \\
\text { materi }\end{array}$ & 1,2 & 2 \\
\hline 2. & Kemudahan & Kemudahan penggunaan media & 3 & 1 \\
\hline 3. & Estetika & $\begin{array}{l}\text { a. Tampilan Media } \\
\text { b. Warna yang digunakan }\end{array}$ & 4,5 & 2 \\
\hline 4. & $\begin{array}{l}\text { Kebutuhan } \\
\text { Pengguna } \\
\text { Jumlah }\end{array}$ & $\begin{array}{l}\text { a. Kebutuhan pengguna terhadap } \\
\text { media } \\
\text { b. Kelayakan media }\end{array}$ & 6,7 & 2 \\
\hline
\end{tabular}

Sumber: (Mubarok, 2015) dengan modifikasi

Uji validasi yang digunakan dalam pengembangan ini meliputi uji validasi ahli atau validasi produk, uji coba oleh praktisi lapangan, uji coba kelompok kecil, dan produk akhir di desiminasi dan implementasi.

\section{HASIL DAN PEMBAHASAN}

Hasil penelitian pengembangan media pembelajaran yang menggunakan model ADDIE, sesuai dengan langkah-langkah ebagai berikut:

\section{Analisis (Analysis)}

Berdasarkan hasil wawancara oleh guru matematika dan peserta didik SDN Sudimara Timur 5, masih banyak peserta didik yang sulit memahami materi matematika. Hal tersebut disebabkan oleh minat belajar matematika yang rendah.

Selanjutnya, berdasarkan hasil wawancara terhadap guru matematika di SDN Sudimara Timur 5, guru tersebut mengatakan bahwa beliau masih mengalami kesulitan dalam menyampaikan materi kepada peserta didik. Hal ini disebabkan karena minat sebagian peserta didik dalam pelajaran matematika masih rendah. Ditambah lagi minimnya fasilitas media pembelajaran yang tersedia disekolah. Selama proses belajar mengajar guru hanya menggunakan buku untuk menyampaikan materi.

Begitu pula dengan wawancara oleh beberapa peserta didik di SDN Sudimara Timur 5, diperoleh bahwa mereka sering merasa bosan ketika pembelajaran matematika, karena metode dan media pembelajaran yang digunakan oleh guru saat pembelajaran matematika selalu monoton. Mereka sulit memahami materi yang diajarkan oleh gurunya. Oleh karena itu, mereka merasa akan sangat tertarik jika ada inovasi dalam pembelajaran matematika, sehingga dapat membantu mereka untuk memahami materi dirumah.

Media pembelajaran matematika yang diinginkan oleh guru matematika maupun peserta didik SDN Sudimara Timur 5 yaitu tidak hanya berisi materi saja, melainkan contoh soal dan soal evaluasi yang menarik. Selain itu tampilan media harus menarik dan terdapat banyak gambar agar peserta didik tidak bosan tetapi materi juga tersampaikan dengan efektif.

Solusi dari permasalahan tersebut adalah ketersediaan media pembelajaran matematika yang menarik dan mudah digunakan. Media tersebut diharapkan dapat menarik perhatian peserta didik pada 
Jurnal Lebesgue : Jurnal Ilmiah Pendidikan Matematika, Matematika dan Statistika

Dini Savitri, Abdul Karim, Hasbullah

Volume 1, No. 2, Agustus 2020 hal.63-75

DOI Artikel : 10.46306/lb.v1i2.17

saat pembelajaran matematika, serta memuat materi yang mudah dipahami peserta didik. Sehingga peserta didik akan dapat menjawab setiap pertanyaan dengan benar. Berdasarkan kebutuhan tersebut, maka disusunlah sebuah media yang dapat memenuhi kebutuhan guru maupun peserta didik. Media tersebut kemudian diimplementasikan dalam pembelajaran metematika

2. Perancangan (Design)

\section{a. Tahap Konsep}

Pengembangan media pembelajaran ini didasari oleh keinginan membuat media pembelajaran dalam pembelajaran matematika yang menarik, yang dapat membantu membantu peserta didik dalam memahami materi. Konsep pengembangan media ini terinspirasi dengan media pembelajaran matematika yang sudah ada.

Materi yang disajikan dalam media pembelajaran ini yaitu materi matematika semester 2 untuk kelas 4 sekolah dasar. Isi materi diambil dari berbagai sumber, diantaranya buku paket dan LKS yang digunakan guru dan peserta didik SD, serta sumber lain seperti modul, internet, dan sebagainya.

b. Tahap Perancangan

Pada tahap ini peneliti mulai membuat flowchart dan storyboard untuk tampilantampilan visual media pembelajaran ini. Beberapa konsep dan perencanaan desain yang dibuat, terinspirasi dari beberapa sumber seperti media pembelajaran matematika yang sudah ada, serta beberapa sumber dari internet. Berikut ini flowchart dan storyboard yang dihasilkan.

\section{1) Flowchart}

Flowchart ini dibuat sebagai acuan bagi peneliti dalam merancang desain media pembelajaran ini, agar alur dan jalur proses pengerjaan media pembelajaran ini dapat dengan mudah dipahami dan dilalui serta diikuti user terutama peneliti sendiri secara menyeluruh dan bermakna. Adapun flowchart yang dibuat adalah sebagai berikut.

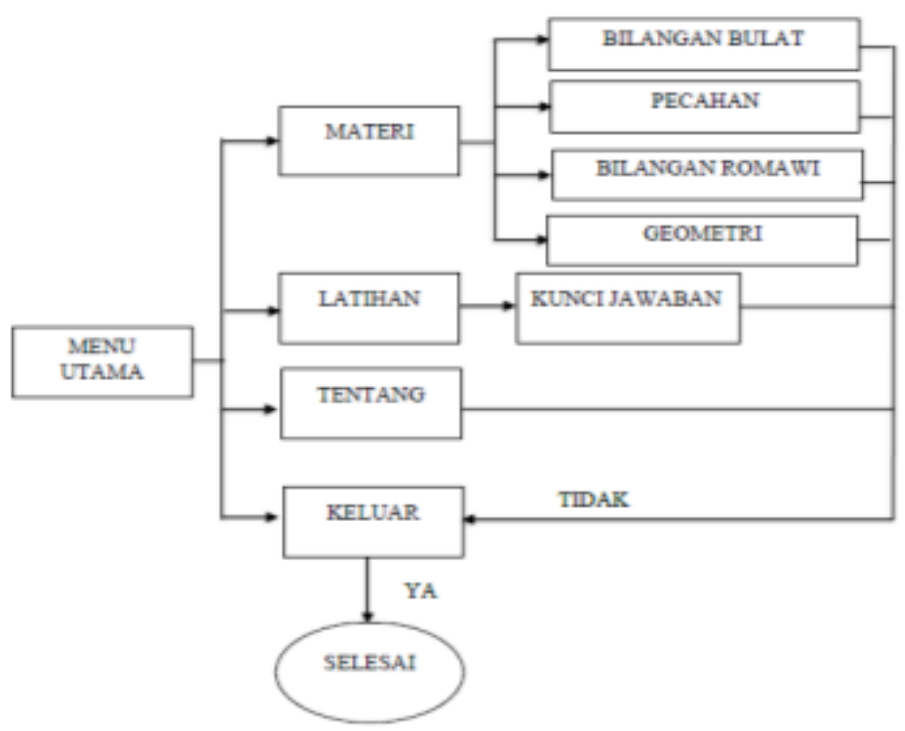

Gambar 2. Flowchart media pembelajaran 


\section{2) Storyboard}

Storyboard ini pada dasarnya pengembangan dari flowchart yang telah dibuat, memuat penjelasan tertulis yang lebih lengkap dari setiap alur yang terdapat pada flowchart. Adapun storyboard media pembelajaran ini yaitu sebagai berikut.

Tabel 4. Storyboard media Pembelajaran

\begin{tabular}{|c|c|c|c|}
\hline No & Keterangan & Visual & Audio \\
\hline 1 & Menu Utama & $\begin{array}{l}\text { Nama media pembelajaran } \\
\text { Tombol-tombol menu Tmbol } \\
\text { navigasi }\end{array}$ & $\begin{array}{l}\text { Saat tombol navigasi di } \\
\text { klik maka akan muncul } \\
\text { efek suara }\end{array}$ \\
\hline 2 & Materi & $\begin{array}{l}\text { Tombol-tombol pilihan materi } \\
\text { Tombol navigasi } \\
\text { Penjelasan materi }\end{array}$ & \\
\hline 3 & Bilangan Bulat & $\begin{array}{l}\text { Contoh soal } \\
\text { Tombol navigasi } \\
\text { Penjelasan materi }\end{array}$ & \\
\hline 4 & Pecahan & $\begin{array}{l}\text { Contoh soal } \\
\text { Tombol navigasi } \\
\text { Penjelasan materi }\end{array}$ & \\
\hline 5 & Bilangan Romawi & $\begin{array}{l}\text { Contoh soal } \\
\text { Tombol navigasi } \\
\text { Penjelasan materi }\end{array}$ & \\
\hline 6 & Geometri & $\begin{array}{l}\text { Contoh soal } \\
\text { Tombol navigasi } \\
\text { Soal-soal latihan }\end{array}$ & \\
\hline 7 & Latihan & $\begin{array}{l}\text { Tombol navigasi } \\
\text { Pembahasan soal }\end{array}$ & \\
\hline 8 & Kunci Jawaban & $\begin{array}{l}\text { latihan } \\
\text { Tombol navigasi }\end{array}$ & \\
\hline 9 & Tentang & $\begin{array}{l}\text { Foto dan biodata } \\
\text { pengembang }\end{array}$ & \\
\hline
\end{tabular}

3. Pengembangan (Development)

Setelah dibuat flowchart dan storyboard pada tahap desain, kemudian peneliti memulai mengembangkan media pembelajaran. Peneliti terlebih dahulu membuat rancangan user interface sebagai gambaran proses pekerjaan yang harus diselesaikan serta gambaran arah tujuan media pembelajaran yang ingin dikembangkan mengikuti flowchart dan storyboard yang telah dibuat. Adapun perancangan user interface sebagai berikut. 
Jurnal Lebesgue : Jurnal Ilmiah Pendidikan Matematika, Matematika dan Statistika Dini Savitri, Abdul Karim, Hasbullah

Volume 1, No. 2, Agustus 2020 hal.63-75

DOI Artikel : 10.46306/lb.v1i2.17

a. Menu awal

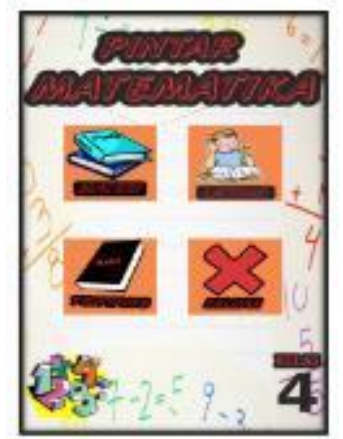

Gambar 4. Menu

d. Pecahan

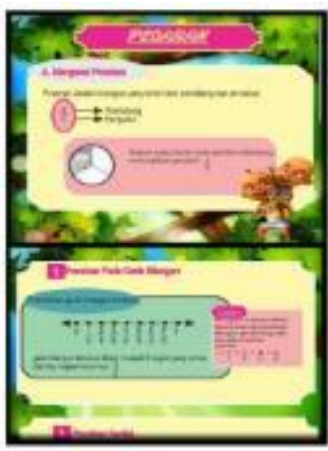

Gambar 7. Pecahan

g. Latihan

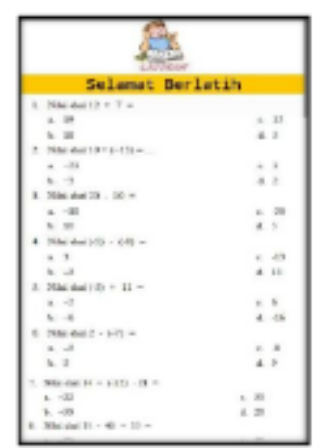

Gambar 10. Latihan b. Materi

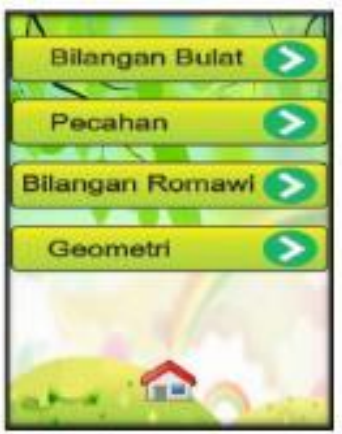

Gambar 5. Materi

e. Bilangan Romawi

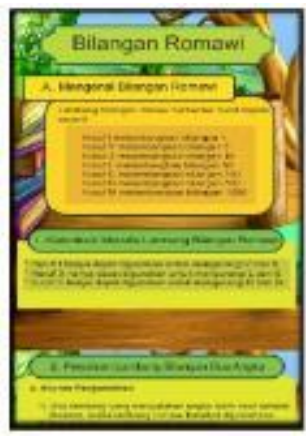

Gambar 8. Bil Romawi

h. Kunci Jawaban

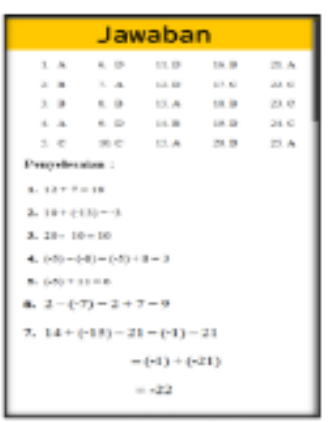

Gambar 11. Kunci Jawaban c. Bilangan Bulat

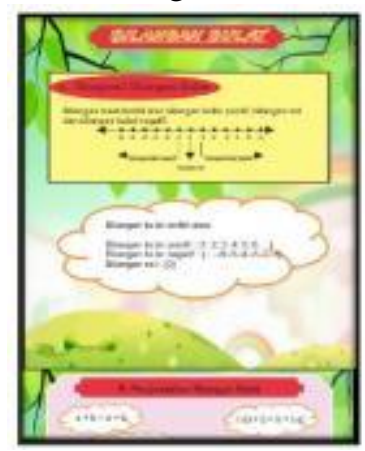

Gambar 6. Bil. Bulat

f. Geometri

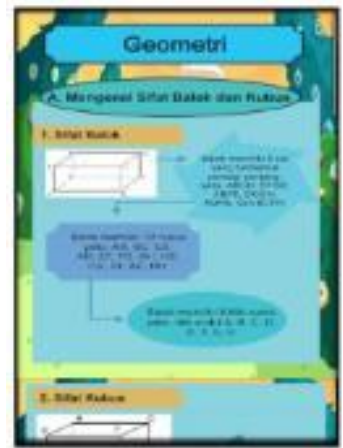

Gambar 9. Geometri

h. Tentang

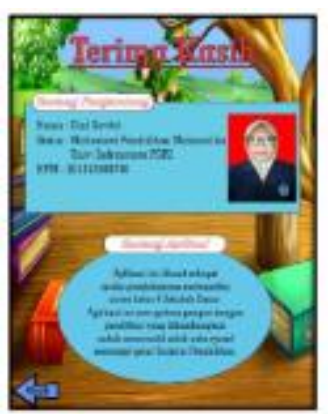

Gambar 12. Tentang

Sebelum media pembelajaran ini dipublikasikan, terlebih dahulu media pembelajaran diuji kelayakannya melalui review oleh ahli. Berikut adalah hasil review oleh para ahli, menghasilkan data rekapitulasi secara kuantitatif dan kualitatif. Review oleh ahli ini dilakukan oleh dosen ahli media pembelajaran dari Pendidikan Matematika dan Guru SDN Sudimara Timur 5 yaitu Indra Martha Rusmana, M.Pd dan Lira Kurnia Putri, S.Pd.

Tabel 5. Review oleh Ahli dan Pengguna

\begin{tabular}{lllll}
\hline $\begin{array}{l}\text { Nomor } \\
\text { Indikator }\end{array}$ & Ahli & Ahli & Pengguna & Pengguna \\
Media & Materi & I & II \\
\hline 1 & 4 & 4 & 4 & 4 \\
\hline
\end{tabular}




\begin{tabular}{lllll}
\hline 2 & 4 & 4 & 5 & 4 \\
3 & 4 & 4 & 4 & 4 \\
4 & 4 & 4 & 4 & 4 \\
5 & 3 & 4 & 5 & 4 \\
6 & 4 & 3 & 4 & 4 \\
7 & 3 & 3 & 5 & 4 \\
8 & - & 4 & 5 & 4 \\
Jumlah & 26 & 30 & 36 & 32 \\
Rata-Rata & 3,71 & 3,75 & 4,5 & 4 \\
\hline
\end{tabular}

Berikut ini adalah hasil data kualitatif yang diperoleh dari kritik dan saran para ahli terhadap media pembelajaran ini.

Tabel 6. Saran dan kritik oleh ahli

\begin{tabular}{clll}
\hline No & Ahli & Saran dan kritik & \\
\hline 1. & Dr. Hasbullah & $\begin{array}{l}\text { Sebaiknya gunakan background yang lebih } \\
\text { menampilkan ciri matematika } \\
\text { Tambahkan efek suara agar lebih menarik dan tidak } \\
\text { membosankan } \\
\text { 2. }\end{array}$ Abdul Karim, M.Pd. & $\begin{array}{l}\text { Latihan soal dibuat lebih interaktif dan tulisan } \\
\text { diperbesar serta tambahkan gambar }\end{array}$ \\
\hline
\end{tabular}

\section{Implementasi (Implementation)}

Implementasi media pembelajaran dilakukan terhadap 3 peserta didik kelas 4 SDN Sudimara Timur 5 dan dilakukan diluar jam pelajaran. Proses uji coba dilakukan dengan menjelaskan cara penggunaan media pembelajaran kepada peserta didik. Setelah peserta didik mencoba, peserta didik diberikan angket respon pengguna media pembelajaran untuk dapat memberi tanggapan tentang media pembelajaran yang dibuat.

5. Evaluasi (Evaluation)

Evaluasi pada tahap pengembangan ini adalah tahap akhir dalam proses pengembangan media pembelajaran. Evaluasi dilakukan dengan menganalisis data yang telah diperoleh dan melakukan revisi tahap akhir terhadap media pembelajaran.

Media pembelajaran yang dikembangkan di review oleh ahli media dan ahli materi. Kegiatan tersebut dilakukan dengan tujuan untuk mengetahui kualias media pembelajaran yang dikembangkan dan kelayakannya. Hasil review oleh ahli media terhadap seluruh aspek yang dinilai rata-rata uang diperoleh yaitu sebesar 3,71 yang berarti termasuk dalam kategori baik, oleh ahli materi diperoleh ratarata sebesar 3,75 dengan kategori baik, serta oleh pengguna yaitu sebesar 4,25 juga termasuk kedalam kategori baik. Sehingga diperoleh rata-rata keseluruhan hasil review ahli dan pengguna terhadap media pembelajaran yang dikembangkan yaitu sebesar 3,90 yang termasuk kedalam kategori baik.

Pembahasan

1. Temuan-temuan dalam Penelitian

Media pembelajaran ini dibuat dengan mengadopsi konsep buku saku, yang disajikan dalam bentuk buku saku digital. Media pembelajaran ini dibuat dengan menggunakan aplikasi online App 
Jurnal Lebesgue : Jurnal Ilmiah Pendidikan Matematika, Matematika dan Statistika

Dini Savitri, Abdul Karim, Hasbullah

Volume 1, No. 2, Agustus 2020 hal.63-75

DOI Artikel : 10.46306/lb.v1i2.17

Inventor dan model pengembangan ADDIE. Media pembelajaran ini terdiri atas 4 menu utama yaitu, materi, latihan, tentang, dan keluar. Materi yang disajikan terdiri atas 4 pokok bahasan yaitu bilangan bulat, pecahan, bilangan romawi, dan geometri. Pada setiap pokok bahasan dilengkapi dengan cara-cara menyelesaikan soal yang dibuat semenarik dan sesederhana mungkin, agar peserta didik dapat memahami dengan mudah. Media ini dilengkapi juga dengan soal-soal untuk latihan peserta didik, dan juga dilengkapi dengan kunci jawaban beserta cara penyelesaiannya. Sehingga peserta didik dapat mengetahui jawabannya benar atau salah. Pada menu tentang berisi informasi mengenai pengembang aplikasi dan tujuan dibuatnya aplikasi media pembelajaran ini. Selain itu, media pembelajaran ini dilengkapi dengan audio yang menarik. Saat tombol pada media pembelajaran ini di klik maka akan muncul audio secara otomatis.

Berdasarkan hasil penelitian yang dilakukan, diperoleh temuan-temuan sebagai berikut:

a. Peserta didik maupun guru SDN Sudimara Timur 5 belum pernah menggunakan media pembelajaran seperti buku saku digital ini, sehingga media yang dikembangkan ini merupakan hal yang baru bagi peserta didik maupun guru.

b. Banyak peserta didik yang tertarik dengan media pembelajaran ini karena memiliki tampilan yang menarik. Sehingga meningkatkan semangat belajar mereka.

c. Desain tampilan media pembelajaran ini telah memalui proses review oleh ahli.

\section{Analisis Data Hasil Pengembangan}

Media pembelajaran yang dikembangkan di review oleh ahli media dan ahli materi. Kegiatan tersebut dilakukan dengan tujuan untuk mengetahui kualias media pembelajaran yang dikembangkan dan kelayakannya. Hasil review oleh ahli media terhadap seluruh aspek yang dinilai rata-rata uang diperoleh yaitu sebesar 3,71 yang berarti termasuk dalam kategori baik, oleh ahli materi diperoleh rata-rata sebesar 3,75 dengan kategori baik, serta oleh pengguna yaitu sebesar 4,25 juga termasuk kedalam kategori baik. Sehingga diperoleh rata-rata keseluruhan hasil review ahli dan pengguna terhadap media pembelajaran yang dikembangkan yaitu sebesar 3,90 yang termasuk kedalam kategori baik. Hasil ini sesuai dengan penelitian Batubara (2017) (Batubara, 2017) yang menghasilkan media pembelajaran matematika berbasis android pada materi bangun datar untuk peserta didik kelas IV SD/MI yang memiliki persentase nilai $87,8 \%$ yang berada pada interval baik dan sangat baik.

\section{KESIMPULAN}

Penelitian pengembangan media pembelajaran matematika SD ini bertujuan menghasilkan produk media pembelajaran yang dapat dijadikan sebagai salah satu alternatif media pembelajaran yang efektif bagi peserta didik yang dapat digunakan untuk belajar mandiri, sehingga dapat meningkatkan hasil belajar peserta didik.

Pada tahap pengembangan dalam kegiatan penelitian ini, media terlebih dahulu direview oleh ahli dan pengguna sebelum akhirnya dinyatakan layak untuk digunakan dalam proses pembelajaran. Hasil review oleh ahli media terhadap seluruh aspek yang dinilai rata-rataulang diperoleh yaitu sebesar 3,71 
Jurnal Lebesgue : Jurnal Ilmiah Pendidikan Matematika, Matematika dan Statistika

Dini Savitri, Abdul Karim, Hasbullah

Volume 1, No. 2, Agustus 2020 hal.63-75

DOI Artikel : 10.46306/lb.v1i2.17

yang berarti termasuk dalam kategori baik, oleh ahli materi diperoleh rata-rata sebesar 3,75 dengan

kategori baik, serta oleh pengguna yaitu sebesar 4,25 juga termasuk kedalam kategori baik. Sehingga diperoleh rata-rata keseluruhan hasil review ahli dan pengguna terhadap media pembelajaran yang dikembangkan yaitu sebesar 3,90 yang termasuk kedalam kategori baik. Berdasarkan hasil review oleh ahli tersebut maka media pembelajaran ini dinyatakan layak untuk diimplementasikan dalam proses belajar peserta didik secara mandiri..

\section{DAFTAR PUSTAKA}

Batubara, H. H. (2017). Pengembangan Media Pembelajaran Matematika berbasis Android untuk Siswa SD/MI. MUALLIMUNA: Jurnal Madrasah Ibtidaiyah, 3(1), 12-27. https://doi.org/10.1016/j.jenvman.2018.01.013

Borg, W. R., \& Gall, M. D. (1983). Educational Research : An Introduction. Longman Inc.

Dewabroto, G. S. (2014). Riset Kominfo dan UNICEF Mengenai Perilaku Anak dan Remaja Dalam Menggunakan Internet. SIARAN PERS NO. 17/PIH/KOMINFO/2/2014.

Fatimah, S. (2009). Matematika Asyik Dengan Metode Pemodelan (I. Y (ed.); Dadan Rama). PT Mizan Pustaka.

Mubarok, F. (2015). Pengembangan Media Pembelajaran Berbasis Mobile Application Menggunakan App Inventor Pada Mata Pelajaran Mekanika Teknik Untuk Siswa Kelas X Studi Keahlian Tgb Smk Negeri 3 Yogyakarta. 140.

Mulyono, A. (2003). Pendidikan bagi anak berkesulitan belajar. Jakarta: Rineka CiptaMulyono, A. (2003). Pendidikan Bagi Anak Berkesulitan Belajar. Jakarta: Rineka Cipta, 33339. Https://Doi.Org/10.1016/j.Jcjo.2015.03.008. https://doi.org/10.1016/j.jcjo.2015.03.008

Rita C. Richey, \& Klein, J. D. (2007). Design and Development Research (A. Messino (ed.); Lane Akers). Lawrence Erlbaum Associates Inc.

Rohmi, O. :, Purbasari, J., Jurusan, M., \& Fmipa, M. (n.d.). PENGEMBANGAN APLIKASI ANDROID SEBAGAI MEDIA PEMBELAJARAN MATEMATIKA PADA MATERI DIMENSI TIGA UNTUK SISWA SMA KELAS X.

Safaat, H. N. (2014). PemSafaat, H. N. (2014). Pemrograman Aplikasi Mobile Smartphone dan Tablet PC Berbasis Android. Informatika. https://doi.org/10.1007/s13398-014-0173-7.2rograman Aplikasi Mobile Smartphone dan Tablet PC Berbasis Android. In Informatika. https://doi.org/10.1007/s13398-014-0173-7.2

Sundayana, R. (2014). Media Pembelajaran Matematika. In Bandung: Alfabeta. Alfabeta. https://doi.org/10.1016/j.sbspro.2016.02.061

Supriyanti, A. (2020). PREDIKSI JUMLAH CALON PESERTA DIDIK BARU MENGGUNAKAN METODE DOUBLE EXPONENTIAL SMOOTHING DARI BROWN ( Study Kasus : SD Islam Al-Musyarrofah Jakarta ). Jurnal Lebesgue : Jurnal Ilmiah Pendidikan Matematika, Matematika Dan Statistika, 1(1), 56-62. https://doi.org/10.46306/lb.v1i1 